\title{
The Federal Role in Forest Management The Continuing Quandary
}

\author{
by
}

Carl H. Winget ${ }^{1}$

\begin{abstract}
The federal role has been redefined almost constantly since Confederation. Change in content and emphasis on various aspects of that role have been almost cyclical. Nonetheless, there now exists a comprehensive and broadly supported definition of this role, the Federal Forest Sector Strategy.

Similar instability has been evident in the roles of the provincial, industrial and other sectors of the forestry community. Here also, reasonable concensus on the definition of these roles is appearing. Success in intensifying forest management will be achieved only if increased investments are supported by broadly acknowledged and relatively stable definitions of the roles of all sectors.
\end{abstract}

\section{Résumé}

Le rôle du gouvernement fédéral a été constamment redéfini depuis la Confédération. Des changements de contenu et d'emphase touchant plusieurs aspects de ce rôle se sont produits d'une façon quasi cyclique. Néanmoins, il existe maintenant un exposé global et généralement reconnu de ce rôle: La Stratégie forestière du gouvernement fédéral.

Semblable instabilité des rôles a été relevée dans d'autres secteurs de la communauté forestière, entre autres chez les gouvernements provinciaux et dans l'industrie. Là encore, un concensus acceptable prend forme quant à la définition de ces rôles. L'aménagement forestier ne pourra être intensifié avec succès que si l'augmentation des investissements n'est soutenu par des rôles bien définis et relativement stables pour tous les secteurs concernés.

\section{Introduction}

This is a subject I approach with considerable interest and some apprehension. Debate on the federal role in Canadian forest management has been going on since Confederation. Sir John A. Macdonald was almost as worried about it as we are. Historically, the federal role could best be described as elastic: its dimensions are easy to describe at any one point in time, but over time they have expanded and contracted in what is almost a sun spot cycle. Some feel this elasticity has been a strength providing flexibility and responsiveness to current needs; others call it a weakness, giving rise to incoherence and contradiction. It has been described as stretching to cover a multitude of sins. Perhaps the only constant in the debate has been nearly continuous criticism, in all probability a healthy situation. One of the basic roles of all levels of government is to be available to bear the blame when things go wrong.

'Director General, Research and Technical Services Directorate, Canadian Forestry Service, Ottawa.
Nonetheless, we now are in the almost surprising position of having a quite comprehensive definition of the federal role, the Federal Forest Sector Strategy for Canada. It has been widely supported and was approved by Cabinet. It has already given rise to initiatives to expand programs, especially the areas of forest renewal, human resources and research. I don't intend to summarize this rather lengthy document and its components. I shall try to place it in perspective and suggest why this subject has been and may continue to be a quandary for the federal government.

The first element is simply that the federal government has little direct control over forests and forest management. Most productive accessible forest land is owned by provinces or is freehold land. That which is controlled by the federal government is mostly dedicated to purposes other than forest production, such as parks and military training. A point to bear in mind is that this simple historical fact is well known to the forestry community, but is not known or is ignored by most Canadians.

The second element is that the federal government has very strong reasons based on enlightened self-interest to actively 
support and promote forest management. Without trying to cite the whole rationale for the "Federal Forest Sector Strategy for Canada", I can at least mention:

a) direct revenues from taxation and the possibility of increasing them through forest management;

b) continuing employment and, conversely, the high costs of unemployment to the federal government;

c) a positive balance of payments in world trade, currently the highest of any Canadian industry;

d) regional economic disparities; and

e) environmental concerns such as acid rain

These two basic elements, lack of direct control and strong self-interest, have often been perceived as being mismatched, almost in conflict. In trying to combine them to form a well defined federal role in forest management, we have in the past created unstable structures which were erected only to quickly collapse. A rapid review of some aspects of the federal role illustrates this instability.

Forestry research has been a relatively constant aspect since the 1930's, although support for it has varied cyclically. This was recognized by the Canada Forestry Act of 1949 and confirmed by its successor, the Forestry Research and Development Act of 1966. However, while the responsible Minister is required by that act to carry out research in forestry, nothing is said about how much shall be done, by whom or where. In fact, in the 15 years following passage of the legislation, the Canadian Forestry Service lost half its scientific manpower. In the past few years, the decline has halted and some increase has occurred, most notably increased interim funding for the fiscal year 1983-84 as a first response to the Research and Development Component of the Forest Sector Strategy for Canada.

That strategy clearly recognizes a need and a rationale for forestry research and the federal role in it, as does the recent report by the Science Council of Canada. We have defined one element of the federal role and implementation has begun. This is highly encouraging. But we've been here several times before.

Another component of the federal strategy is now a reality. The Human Resources Program provides funding increasing from $\$ 3.5$ to $\$ 6$ million over three years to support university research and graduate training in forestry, as well as summer employment for 300 forestry students and 50 Canada forestry scholarships for graduate students. This is already proving very effective and represents another well defined federal role relating to forest management. But this is not a new idea. The previous system of Canadian Forestry Service grants to forestry schools had simply dwindled in purchasing power because of inflation and through the increase in the number of forestry schools to the point of having almost negligible effect.

Interestingly, that same Forestry Research and Development Act also gives the responsible minister wide discretionary powers to do almost anything to promote forest management, if he can find willing partners, but doesn't require him to do anything except research. This has certainly been reflected in the history of Forestry Development Agreements. In the fifties and sixties, federal-provincial agreements with the Canadian Forestry Service as the responsible federal agency concentrated quite effectively on access to the forest resource and, to some degree, forest protection. These disappeared and were replaced in the seventies by the Department of Regional Economic Expansion's sub-agreements for forest development with some provinces. Concern for regional economic disparity and local unemployment decreased emphasis on forest management for wood production. These are now being replaced by a new generation of Forestry Development Agreements being negotiated by the CFS with provinces. These concentrate on forest renewal and should increase federal investment in this area from $\$ 50$ to perhaps $\$ 130$ million annually. This key component of the Federal Forest Sector Strategy should provide considerable stability to forest renewal efforts, at least for the next five years, and hopefully through the transition period from wild to managed forest. This is the third try, so perhaps we shall carry through.

One may glance quickly at some other aspects of the federal role. The Forest Insect and Disease Survey, like research, has also been around a long time. Once a part of the Department of Agriculture, it still operates on delegated authority from Agriculture Canada and the Pest Control Act. The Survey's career, which like medicine and journalism thrives on disaster, has not only varied over time, it still differs drastically from province to province and epidemic to epidemic.

A closely related activity has been the Canadian Forestry Service role in reporting forest inventory data at the national level, in this case a delegation of authority from Statistics Canada. Only since the 1980 approval by the Canadian Council of Research and Environment Ministers of the report "Forestry Imperatives for Canada" have we developed a reasonable concensus on the federal role in this area. Its extension to include forest management information is now being addressed.

One can also cite the example of forest economics. During the sixties, the CFS developed a Forest Economics Institute, which crashed to a few scattered economic advisors and is now being re-built, largely in response to needs relating to Forestry Department Agreements.

Forest management on federal lands was the central theme of the federal role at the turn of century. It has greatly diminished with the transfer of lands to provinces and allocation to non-forestry uses and is fragmented among various agencies. Concern is being expressed and new initiatives may develop.

I could go on, but I think the point is clear. Many approaches have been tried and abandoned. Roles and responsibilities have been defined and redefined in almost haphazard fashion. The pattern has been inconsistent and incoherent.

Once again, the federal role in forest management is in a period of development and expansion to meet perceived needs. Once again, reasonable concensus is developing on this role, at least in broad outline. Once again, the possibility of some stability in that role is appearing. In a context of serious economic difficulties generally, and in the forest industry particularly, we have made remarkable progress in both policy and programs. The question I find myself obliged to ask is, "For how long?"

My thumbnail sketch, perhaps mildly exaggerated, was not intended as a catalogue of criticisms and complaints. On the contrary, one must recognize that these changes were conceived as logical, reasonable answers to forest management needs as perceived at given moments. Further, one must recognize that many of these changes were generated by serious, intelligent soul-searching within the forestry community itself. Others were imposed because the forestry community was too divided, too distracted by other concerns or simply too uncommitted to find good alternatives to questionable proposals. And therein lies the quandary. Will the forestry community as a whole maintain a minimum of concensus on the federal role and the roles of other sectors long enough to attain some degree of stability?

The elastic nature of the federal role in forest management is particularly obvious because it is, by definition, indirect, almost residual. All levels of government "tax where they can and spend where they must". If needs are not perceived and communicated as "musts", they are neglected. Perception and communication in the past has been, at best, sporadic. There has been too little continuity and too few concrete results in the management of forests to be truly convincing. I 
suggest that the federal government has not been alone in this respect. There have been some rather extreme changes and about-faces in the roles and responsibilities of provinces, industry and, indeed, all sectors of the forestry community.

It is often stated that foresters are ultra-conservative and suspicious of change. At least as far as institutional roles and responsibilities are concerned, this may well be true. In this area, change in Canada has been more confusing than beneficial. There is little evidence that we have learned from experience or built on acquired knowledge. A certain degree of cynicism is inevitable. On the other hand, to search for complete and permanent concensus on the precise roles of all sectors would be unrealistic and unhealthy. To strap ourselves into a legislative strait jacket would be foolish. What we must find is that essential balance between flexibility and continuity, recognizing that in the past we have been flexible to the point of being inconsistent, almost incoherent.

Canada is now entering the "make or break" era for its forest resource and forest industry, just as Scandinavia did in the forties, the southeastern U.S. in the fifties and the northwestern U.S. in the sixties. Our future is very much at risk, just as theirs was. I believe we shall succeed, just as they did, and that the rewards will be equally great.

But, to succeed, we must first, as those countries have, agree on who does what. By its nature, forest management requires reasonable stability in roles and reasonable consistency in action. In the past, we have created and abandoned role definitions too often to provide that stability. Increasing investments in forest management will only succeed if efforts are concerted and, above all, sustained. We need evolution, not revolution.

In recent years, we have come surprisingly close to reasonable consensus on the federal role in forest management. A similar evolution is apparent for other sectors. This is a valuable, in fact, essential point of departure for the coming struggle to manage forests intensively. This time we must not fritter away the advantage. We must sustain it and build on it.
Tel.: (819) 326-3559

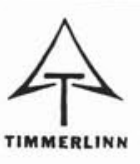

TIMMERLINN LMMTEE

PROFESSIONAL AND TECHNICAL SERVICES IN FORESTRY AND ENVIRONMENTAL SCIENCES

R.R. No. 2, STE. AGATHE DES MONTS, QUE. J8C $2 Z 8$
Woodlot Service (1978) Ltd.

"All Matters Pertalning to Forestry"

\author{
GORDON B. YOUNG, B.Sc.F., M.F. \\ Registered Professional Forester
}

